EGU Stephan Mueller Special Publication Series, 2, 1-5, 2002

(C) European Geosciences Union 2002

\title{
Introduction
}

\section{From continental extension to collision: Africa-Europe interaction, the Dead Sea Rift and analogue natural laboratories}

\author{
Editors: S. A. P. L. Cloetingh (Amsterdam), Z. Ben-Avraham (Tel Aviv)
}

This volume contains a selection of papers presented at the Stephan Mueller Conference of the European Geophysical Society in the Dead Sea area on the theme "From continental break-up to collision: the Dead Sea rift and other natural laboratories". The Dead Sea provides a well-constrained natural laboratory (see Ben-Avraham, 2001) to study the processes of continental break-up in a key setting in the context of the dynamic interaction of Europe and Africa (Fig. 1). The interplay of lithospheric processes and surface processes manifest in the topography of the area, with the Dead Sea the lowest depression on the continents, has been a topic central in the focus of the meeting. Environmental tectonics is a rapidly developing field of research (e.g. Cloetingh, 2000; Cloetingh et al., 2002) and the Dead Sea rift provides a spectacular site to study the effects of the interplay of active tectonics and climate on human habitat. In the last few years, major international research efforts have been initiated in the Dead Sea area and several international workshops, including a Task Force Meeting of the International Lithosphere Program in 1994, have adressed issuses such as the relationship between lithosphere evolution and basin formation in the area (Cloetingh et al., 1996).

In the last decades a number of syntheses have been published on the overall tectonic evolution of the area (e.g. BenAvraham, 1997; Garfunkel and Ben-Avraham, 1996; Niemi et al., 1997), providing a framework for future research. In the mean time, the first joint Israel-Jordan studies have been carried out, integrating data from both sides of the rift, providing for the first time an internally consistent picture of the transform system (DESERT Team, 2000; Al-Zoubi and Ben-Avraham, 2002; Al-Zoubi et al., 2002). Beside Israel and Jordan, other countries border the Dead Sea rift, including Saudi Arabia, Egypt, the Palestinian Authority, Lebanon, Syria and Turkey. More joint studies involving scientists from the region and outside are needed for better understanding of this unique feature.

Fundamental questions remain to be addressed on the thermo-mechanical structure of the Dead Sea rift system. Of particular importance in this context is the influence of litho- spheric memory on bulk rheological properties of the lithosphere in extensional and strike-slip regimes (e.g. Cloetingh et al., 1995) and the feed back of lithospheric processes and surface processes (e.g. Burov and Cloetingh, 1997). New deep seismic data (DESERT team, 2000) and quantitative estimates on differential topography development in the Dead Sea rift system through time provide new constraints on dynamic models for continental break-up (e.g. Van Wijk and Cloetingh, 2002) to be tuned to specific conditions pertinent to the Dead Sea rift system.

The papers of this volume illustrate the multidisciplinary nature of the ongoing research on the connection of surface processes and lithospheric dynamics. The papers (see Fig. 2 for geographical location) provide a survey of various methodological approaches required to provide an integrated picture of the processes and their surface expression.

The first set of papers concentrate on the Dead Sea area. In the contribution by Wust-Bloch an analysis is given of several types of earthquake-induced failure features in the Dead Sea Rift. This work sheds light on the importance of deviations from habitual damage distribution patterns reported for other areas. On the base of these findings and a series of unusual seismic characteristics, the authors propose that the structure of the Dead Sea Rift influences the dissipation of seismic energy and acts as a wave guide.

Eyal et al. discuss controls by failure due to basin-ward gravitational mass movement and tectonic activity on faulting and deformation of fan deposits located near active tectonic zones. These authors concentrate on the criteria required to distinguish between the two failure mechanisms and the importance for assessment of seismic risk and seismic recurrence time of such terrains. Eyal et al. present evidence for a close spatial association between subsurface faults, determined in seismic profiles and overlying deformation features mapped in the field, concentrating on a geological and seismic study of the Nahal Darga fan delta of Holocene age located on the western margin of the Dead Sea Transform. 


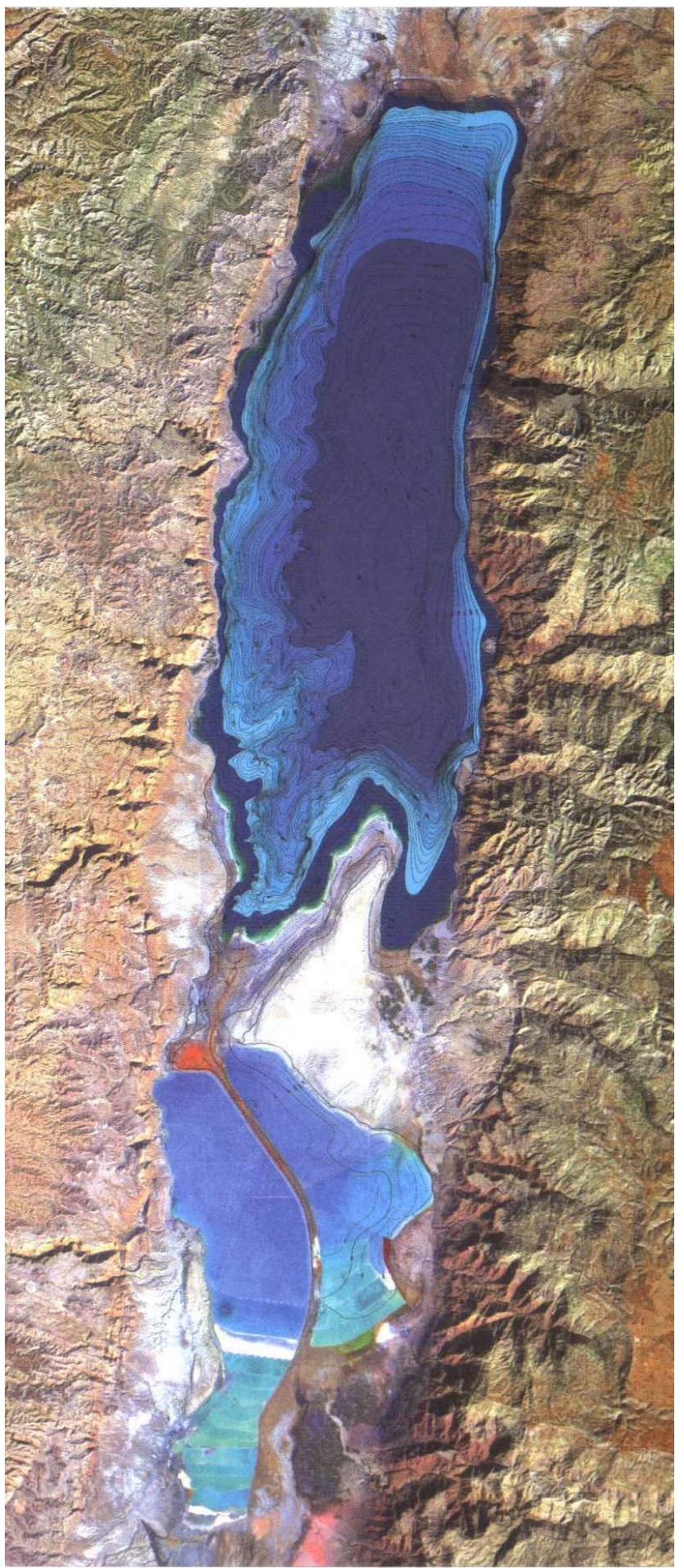

Fig. 1. Satellite image of the Dead Sea from the Israel Satellite Map at scale 1:322 500 (Historical Productions, Ltd., Educational Programs, Inc., 1990). This image with $10 \mathrm{~m}$ pixels was obtained by merging a LANDSAT 5 scene from 18 January 1987 with higher resolution panchromatic imagery of Israel from the French SPOT satellite. Copyright Historical Productions, Ltd. And C.N.E.S.; reproduced by permission.
Basson et al. present the results of ground penetrating radar imaging conducted across the Evrona fault zone up to a depth of 25 metres below the surface, revealing a dense inhomogeneous distribution of subsurface dicontinuities. These authors interpret the results of their findings in terms of a set of fractures with a variety of dip-slips, spatial orientations and depths, merging at depths of a few tens of metres. Shallow seismic reflection studies in the area identify a parent fault below the group of faults detected by ground penetrating radar.

Atallah et al. present the results of a detailed stratigraphic and structural study of the southeast Dead Sea basin in Jordan to constrain the deformation history and processes of pull-apart formation. Their data agree with a model for Dead Sea pull-apart formation, explaining the activity of transverse faults as younger than the formation of the basin. The authors present the results of paleo-stress analysis pointing to a polyphase stress history. The first stress regime appears to represent the Syrian Arc stress field, whereas the second stress field orientation is consistent with the regional stress field in the Dead Sea rift.

Eldeen et al. present results from paleostress investigations on fault-slip data along the eastern margin of the Dead Sea rift. Their work shows evidence for a general clockwise rotation with time of the main axis of horizontal compression from an E-W trend in the Creataceous to a N-S trend in the Pleistocene. Their data also show the appearance of E-W extension in the Late Peistocene, superimposed on the Dead Sea stress field. On this base, the authors propose that the Dead Sea Rift System formed in a combination of strike-slip and dip-slip movements.

De Jaeger and De Dapper focus on the tectonic control of the geomorphologic development of the Wadi El-Mujib canyon of Jordan. The authors review the drainage evolution of Central Jordan and the Wadi Mujib Basin. In this area canyon development took place at the eastern shoulder of the Dead Sea. These authors point out that fluvial incision occurred preferentially along tectonic lines characterized by rock weakness and discontinuities. Climate changes are reported to be probably the principal cause for several types of Pleistocene deposits in the canyon but tectonic influence often appeared to play an additional role.

Belitzky concentrates on a morphotectonic study of young structures and movements in the central segment of the Dead Sea rift, along the lower Jordan Valley. This work includes analysis of relief, drainage network and remote sensing images. In the absence of evidence for lateral displacement, uplifted and subsided areas along the lower Jordan Valley are interpreted by this author as a reflection of vertical rather than lateral motions. Belitzky therefore argues in favour of a neotectonic regime dominated by continuous $\mathrm{N}-\mathrm{S}$ extension of the Israel-Sinai plate and by transverse motions during the Arabian plate "escape".

Shaked et al. study fossil shorelines at the southern end of the Dead Sea Transform. Data from coral reef terraces and beach rocks yield constraints on the evolution of the coastal 

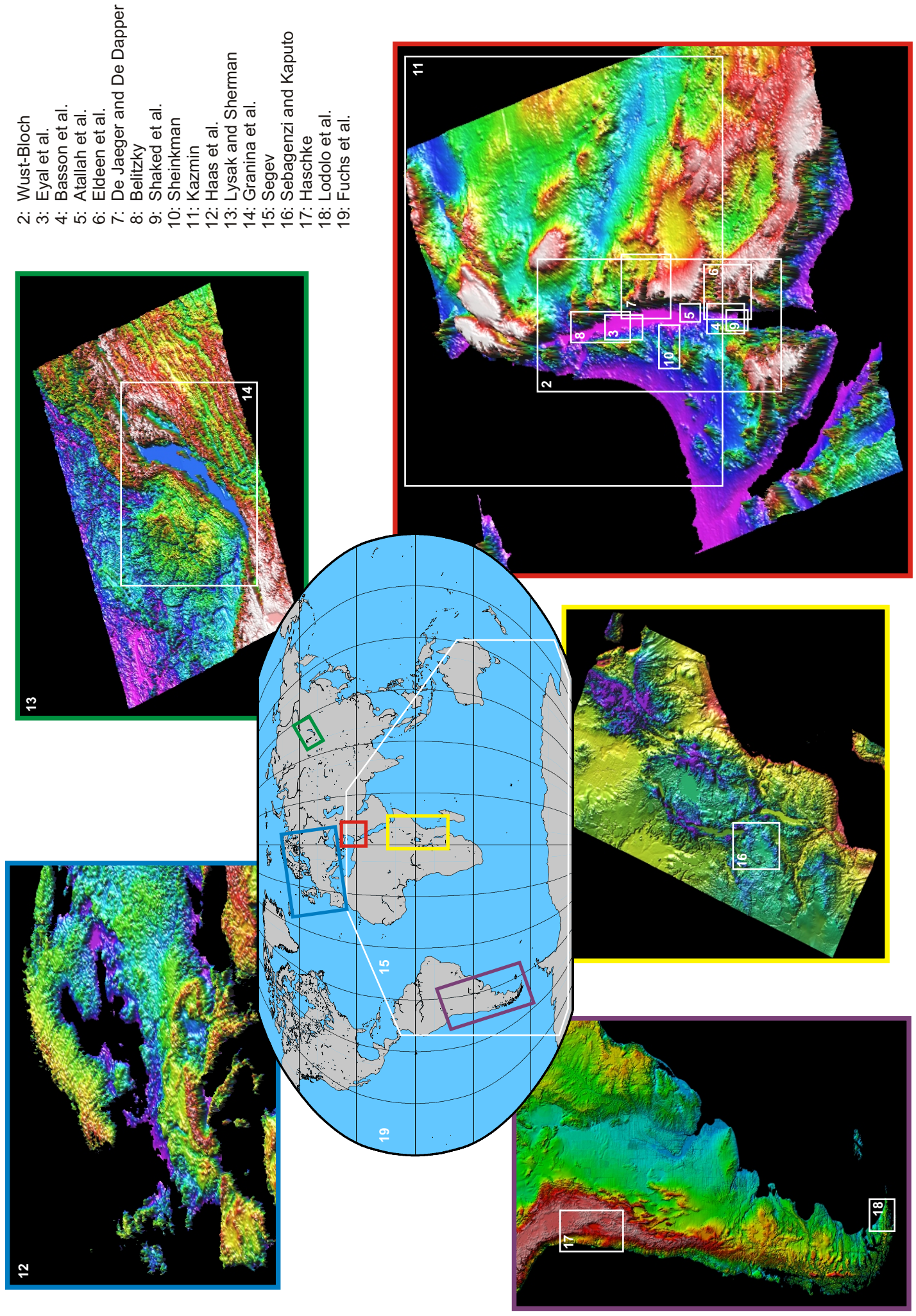
margin of the Gulf of Aqaba. These authors suggest that eastward propagation of the Holocene shoreline reflects a delayed response to tectonic changes in coastal bathymetry or the result of climatic events.

Sheinkman presents evidence for invasion of the Lake Lisan, the precursor of the Dead Sea, from preserved lacustrine sediments along the Lower Zin Valley at a distance of $25 \mathrm{~km}$ from the present coast of the Dead Sea. This author has studied terraces and discusses results from TL dating, arguing that other fluctuations in the level of the Dead Sea and its Pleistocene precursors also exerted an influence on the development of the Zin Valley.

The next group of two papers concentrate on large-scale effects of Europe-Africa interaction:

Kazmin discusses several stages of intraplate deformation in North Arabia from the Late Paleozoic to Cenozoic. This author distinguishes major rifting phases in LateCarboniferous - Permian, Middle-Late Triassic and at the end of Early Cretaceous and argues for the absence of a clear connection with plume activity. A correlation of Arabian passive margin collision and inversion phases in North Arabian rift basins and in North Sinai is presented as well as evidence for correlation of later stages of inversion with Africa-Eurasia and Arabia-Eurasia collision. The author argues in favour of slab pull as the driving mechanism behind intraplate deformation in North Arabia.

Haas et al. present the results of an analysis of observations of the European geodetic VLBI network. These results show evidence for horizontal deformation due to postglacial rebound in the northern part of the VLBI network, with vertical motions exceeding predictions from post-glacial rebound. In the southern part of the network horizontal motions reflect the complex nature of the interaction in the Africa- Europe collision. The authors present the results of a large-scale strain rate analysis, based on the geodetic data base. Maximum strain-rates are found in the eastern Mediterranean area.

The following two papers focus on the Baikal rift natural laboratory:

Lysak and Sherman review heat flow data in the Baikal rift zone. These authors point out that the terrestrial heat flow in the Baikal rift zone is irregularly distributed. High heat flow is commonly associated with active faults. Across the fault strike, heat flow decrease with distance from the fault axis.

Granina et al. report on anomalies in pore-water composition found in core in the Southern Lake Baikal. These authors show a genetic relationship between sub-aquatic and terrestrial centres of thermal water discharge in Northern Lake Baikal. In Southern Lake Baikal, in the Selenga River delta, ground waters of specific composition that are relics of ancient salt lakes appear to serve as a source of anomalous concentration of pore water components. The authors discuss the relevance of their findings in the context of the seismicity of the Baikal rift zone.

The final set of five papers highlight aspects of manle structure, upper mantle dynamics and continental break-up tectonics in the southern hemisphere.

Segev presents the results of an analysis of igneous provinces, flood basalts and the mechanics of continental break-up. This author argues in favour of an important role of sub-lithospheric migration of plumes in the dispersal of Gondwana.

Sebangenzi and Kaputo review gravity, heat flow and seismological data to constrain recent rifting in Central Africa. From an analysis of relationships between Bouguer anomalies and topographic elevation, the authors argue in favour of astenospheric upwelling from Early Cenozoic on, simultaneously with the onset of Arabia-Africa rifting and development of the East African rift system.

Haschke et al. study the connection between geochemical tracers of Andean orogeny and Archean crustal growth. These authors focus on the Late Cretaceous - Eocene arc, exploring the evolution of geochemical and isotopic signatures of arc magmatic rocks through time. Support for the timing and magnitude of crustal thickening comes from similarities with chemical signatures from the modern southern volcanic zone, from trace element modeling and from regional geologic constraints. The results of this work support earlier models of Archean crustal growth and a significant role for generation of continental crust by recycling mafic underplate of thick orogenic crust.

Lodolo et al. present the results of field geological studies, combined with SPOT maps and Synthetic Aperture Radar images of the morphostructural evolution of the centraleastern Tierra del Fuego Island at the southernmost tip of the South American continent. These authors discuss the connections between their findings and the Magallanes-Fagnano fault system, one of the major portions of the present-day South America-Scotia plate boundary. They draw attention to the connection of the tectonic lineaments and the development of fault-controlled basins and their superposition on pre-existing fold and thrust belt systems.

Fuchs et al. review the importance of the lithospheric mantle as a waveguide for high frequency long-range propagation of thousands of kilometres. They point to significant features characterizing the waveguide, including a change in scale-length of velocity fluctuations at Moho level recognized from the coincidence of the Moho in seismic reflection and refraction studies. Another striking feature appears to be the ability to propagate long-range seismic waves and their disappearance at plate boundaries. On the base of these findings authors point to a connection with the mechanical coupling of the convecting mantle to the overlying plates.

Acknowledgements. The Stephan Mueller Conference was organized by the Minerva Dead Sea Research Center, Tel Aviv University. We thank ORTRA Ltd. for logistic support and Tel Aviv University, and EGU, the International Lithosphere Programme (ILP) and the Netherlands Research Centre for Integrated Solid Earth 
Science (ISES) for financial contribution. We finally would like to thank all the reviewers for their effort in constructively and thoroughly reviewing the papers submitted to this volume. Karen Leever and Sandra Merten are thanked for editorial assistance. This is ISES contribution 2002.0719.

\section{References}

Al-Zoubi, A. and Ben-Avraham, Z.: Structure of the Earth's crust in Jordan from potential field data. Tectonophysics, 346, 45-59, 2002.

Al-Zoubi, A., Shulman, H., and Ben-Avraham, Z.: Seismic reflection profiles across the southern Dead Sea basin. Tectonophysics, 346, 61-69, 2002.

Ben-Avraham, Z.: Geophysical framework of the Dead Sea, in: Miemi, T. M., Ben-Avraham, Z., and Gat, J. (Eds.): The Dead Sea: The Lake and its setting. Oxford University Press, New York, 22-35, 1997.

Ben-Avraham, Z.: The Dead Sea - a unique global site. European Review, 9, 437-444, 2001.

Burov, E. B. and Cloetingh, S. A. P. L.: Erosion and rift dynamics: new thermo-mechanical aspects of post-rift evolution of extensional basins. Earth Planet. Sci. Letts, 150, 7-26, 1997.

Cloetingh, S. A. P. L.: Perspectives on Environmental Earth System Dynamics, Global Planet. Change, 27, 1-21, 2000.
Cloetingh, S. A. P. L., Ben-Avraham, Z., Sassi, W., and Horvath, F. (Eds.): Dynamics of extensional basins and inversion tectonics. Tectonophysics, 266, 1-523, 1996.

Cloetingh, S. A. P. L., Horvath, F., Bada, G. and Lankreijer, A. (Eds.): Neotectonics and Surface Processes: the Pannonian Basin and Alpine/Carpathian System. EGU Stephan Mueller Spec. Publ., 3, 2002.

Cloetingh, S. A. P. L., van Wees, J. D., van der Beek, P. A., and Spadini, G.: Role of pre-rift rheology in kinematics of extensional basin formation: constraints from thermomechanical models of Mediterranean and intracratonic basins. Marine and Petroleum Geology, 12, 793-808, 1995.

DESERT Team, DESERT 2000: multinational geoscientific research effort kicks off in the Middle East. EOS, Trans. Am. Geophys. Union, 81, 609-617, 2000.

Garfunkel, Z. and Ben-Avraham, Z.: The structure of the Dead Sea basin, Tectonophysics, 266, 155-176, 1996.

Niemi, T.M., Ben-Avraham, Z., and Gat, J.R. (Eds.): The Dead Sea:, the Lake and its setting. Oxford Monographs on Geology and Geophysics, Oxford University Press, New York, 1-286, 1997.

Van Wijk, J. and Cloetingh, S. A. P. L.: Basin migration caused by slow lithospheric extension. Earth Planet. Sci. Letts., 198, 275288, 2002. 